\title{
Analysis of Regional Economic Sector Shift And Growth in Palopo City Based On Shift Share Application
}

\author{
Fika' $^{1}$, Muhammad Yusri Zamhuri ${ }^{2}$, Nixia Tenriawaru ${ }^{3}$ \\ ${ }^{1}$ Postgraduate Program in Regional Planning, Hasanuddin University Jl. Akasia, Kec. Wara Timur, Kota Palopo, Sulawesi Selatan, 90921 \\ ${ }^{2}$ Economic Sciense and Bussiness, Hasanuddin University,Perintis Kemerdekaan KM. 10 , Kec. Tamalanrea, Kota Makassar,Sulawesi Selatan, 90245 \\ ${ }^{3}$ Agribisnis Technology, Hasanuddin University,Jl. Toddopuli 10, Kec. Manggala, Kota Makassar,Sulawesi Selatan, 90234
}

Correspondence Author: Fike, Postgraduate Program in Regional Planning, Hasanuddin University Jl. Akasia, Kec. Wara Timur, Kota Palopo, Sulawesi Selatan, 90921

E-mail: fika0587@gmail.com

Received date: 28 August 2019, Accepted date: 15 November 2019, Online date: 26 November 2019

Copyright: @ 2019 Fika et al., This is an open-access article distributed under the terms of the Creative Commons Attribution License, which permits unrestricted use, distribution, and reproduction in any medium, provided the original author and source are credited.

\begin{abstract}
Leading sector commodity is the main driver of the regional economy of Palopo City. Effective and efficient management of the economic sector can increase investment and create new jobs. The economic sector is categorized as superior having several criteria including high growth rate (productivity), high sectoral added value, competitive advantage and specialization. Therefore an in-depth analysis of growth and sector shift is needed to determine the leading sector in Palopo City based on established criteria determined. This research is a quantitative study using secondary data in the form of PDRB Palopo City and South Sulawesi Province time series 2013-2018. Data analysis techniques are the Classic Shift Share and Shift Share Analysis Marguillas. The results of the calculation of the Shift Share analysis of the growth and shift of the economic sector in Palopo City indicate that the electricity and gas procurement sector; wholesale and retail trade, car and motorcycle repair; information and communication; and health services and social activities have the value of proportional shift (PS), differential shift (DS) and net shift (net shift) are positive means the sector has a fast growth rate, high competitiveness and progressive (advanced). While the results of the analysis of Shift Share modification Estaban Marguillas shows that the electricity and gas procurement sector; wholesale and retail trade, car and motorcycle repair; transportation and warehousing; real estate; and health services and social activities are specialized sectors and have a competitive advantage in the City of Palopo. Based on an analysis of growth and shifts in the regional economic sector in the City of Palopo, it shows that the sectors that meet the leading sector criteria together are high growth (productivity), competitive advantage, specialization and high added value are the electricity and gas procurement sector ; wholesale and retail trade, car and motorcycle repair; health service sector and social activities.
\end{abstract}

Keywords: Economic growth, Classic shift-share analysis, Estaban Marguillas shift share, Competitive advantage and Specialization

\section{INTRODUCTION}

Since the era of regional autonomy, the system of regional government administration has been delegated from the central government to regional governments. Regional economic development aims to improve the welfare and prosperity of the people. The success of economic development is highly dependent on the policies and regulations made by the region in determining sectors that are the top priority for encouraging regional economic growth (Amalia, 2012). Economic growth in Palopo City is quite stable, only it showed a slowdown wherein 2013 it had reached $8.02 \%$, it had to go down in 2014 to $7.05 \%$, in 2015 it fell again to $6.47 \%$ and in 2016 it rose to $6,95 \%$, in 2017 it will be $7.17 \%$ and in 2018 it will be $7.52 \%$. The slowing economic growth was caused by the decrease in contribution from the wholesale and retail trade sector, car and motorcycle repair. As for the growth rate of the wholesale and retail trade sector, car and motorcycle repairs, namely in 2013 amounted to $15.28 \%$, in 2014 amounted to $13.26 \%$, in 2015 amounted to $12.21 \%$, in 2016 amounted to $10.84 \%$, in 2017 amounted to 10 , $19 \%$ and in 2018 amounted to $9.15 \%$.

The government through the Palopo City RPJMD in 2018-2023 set the wholesale and retail trade sector, car and motorcycle repair to be a leading sector because it has a contribution to the regional economy. But according to Arsyad that the sector with the largest contribution to the total regional economy (GDP) has not been adequately categorized as a leading sector (Gunawan, 2015). Determination of leading industries is needed as the main driver of the regional economy of Palopo City. Regions that are unable to develop their sectoral potential effectively and efficiently tend to be left behind and underdeveloped (Brown, Greskovits and Kulcsár, 2007). Regional economic sectors can be categorized as leading sectors based on high growth rate (productivity) criteria, high sectoral added value, competitive advantage and specialization. Based on these conditions further analysis of sector shifts and growth is needed as an effort to identify the leading sectors of the City of Palopo based on predetermined criteria. 


\section{a. Gap of the problem}

Based on this description, the focus of the problems that formulated in this study are as follows:

1. How is the shifting and growth of the sector for the economic development of the City of Palopo?

2. What sectors are the leading economic growth in Palopo City?

\section{b. Research purposes}

The purpose of this study is based on the problem formulation as follows:

1. Analyzing sectoral shifts and growth in the economic development of the City of Palopo.

2. Analyzing the sector which is the leading economic growth in Palopo City.

\section{LITERATURE REVIEW}

\section{Regional Economic Development}

Regional economic development aims to improve the welfare and prosperity of the local community. Governments as regional stakeholders need to develop quality, fair, sustainable and environmentally sound economic development policies, especially those directly related to the utilization of the potential and resources of the region. Basically the regional economic principles are similar with the principles of the national economy. Economic development of each region varies depending on the potential and availability of natural resources owned by the region. To develop the regional economy, the government is expected to be able to develop and utilize the potentials that are owned and pay attention to the aspirations of a growing and developing community (Badri, 2009). Regional economic development is determined by the availability of capital by knowing the potential that is superior to the region, resulting in appropriate development and management policies. The quality of goods and services produced through appropriate management processes can increase market demand from both inside and outside the region. According to Nugroho, economic interaction between regions is unavoidable because each region needs each other, especially in meeting the needs of their respective regions (Sun'an and Senuk, 2015). Regional economic development is a major component that drives the acceleration of regional economic growth. Identification of leading regional sectors is needed to increase demand for the production of goods and services in it and provide a multiplier effect for increasing regional income flows, boosting investment and creating new jobs in the region.

\section{Economic growth}

Economic growth is part of regional economic development. In general, regional economic development is not only measured through the GDP but also considers other social problems involving unemployment rates, the percentage of poor people and the availability of new jobs. Economic growth is a process that causes income per capita population to increase in the long term (Syahputra, Hamzah dan Syahnur, 2015). Growth is seen as a continuous and continuous process that involves major changes to the social structure and ideological values of the nation. Fluctuating regional economic conditions describe economic growth that occurs within a certain time. The level of economic growth in an area is very much determined by government policies in particular in the economic field. Economic growth is significant in the process of formulating regional policies because it provides an overview of the condition of the regional economy and how the social impact it causes for the wider community. Based on the economic base theory, economic growth is directly related to the amount of demand for goods and services from outside the region or the amount of export value of goods and services out of the region. The main constraint of economic growth in a region is not on the supply side but the real challenge means that the constraints on growth. the economy is not investment, capital availability or ability but is influenced by the large demand for goods and services produced by the leading sector of the region (Chandra, 2006). Mutual relations between sectors within the scope of the regional economy as a whole are expected to stimulate the growth of the non-base and non-leading sectors in the region.

\section{The Concept of Regional Competitiveness}

Competitiveness is very important to maintain the existence of products and services that are superior regions that are oriented to the quality of the production process and the quality of the output produced. Competitiveness is very necessary to encourage the economic performance of a region. Competitiveness is something abstract and invisible, appearing in the form of competition between actors and the economic sector. Regional competitiveness occurs when each sector and commodity which is a superior region fight for markets outside the region by highlighting the superiority of the products offered. This condition will attract market interest from outside and increase demand for goods and services from other regions. Regional competitiveness is not only focused on government efforts to expand the market for goods and services produced but in the broader context the concept of regional competitiveness can be interpreted as an effort which is carried out by the government in improving the welfare of its people. Competitive advantage (regional competitiveness) is more directed at the ability of regions to produce goods and services that can compete with products from other regions in the national/foreign/global market. An area that has a competitive advantage can be seen from the contribution of exports of goods and services to the increase in regional income.

\section{METHODOLOGY}

\section{Data types and sources}


This research was conducted in Palopo City, South Sulawesi Province. As for the method in this study, it was quantitative, where the data used was secondary data in the form of GRDP in Palopo City and Sulawesi Province Selatantime series 2013-2018 from BPS publications.

\section{Data analysis method}

According (Muta'ali, 2015) classic Shift Share Analysis is used to determine the magnitude of sectoral added value which is influenced by three main components of regional growth, namely Regional Share (RS), Proportional Shift (PS) and Differential Shift (DS). Proportional shift (PS) gives a picture of the relative change in the growth of the regional sector compared to the growth of the same sector at a broader level (National / Province). Differential shift (DS) gives an idea of how far the change in competitiveness of the regional economic sector is compared to the competitiveness of the same sector at a broader level (National / Provincial). Based on the three components, a net shift value (SNij) value can be obtained that can be used to identify regional sector growth whether progressive or not progressive. According to Soepono, the Proportional Shift (PS) and Differential Shift (DS) components are more critical than the Regional Share component in the analysis of regional economic growth (Muta'ali, 2015). According Muta'ali that the interpretation of the PS and DS values are as follows:

The meaning of PS (Mij)

a. PS (Mij) value negative or $<0$ indicates that the growth rate of sector $i$ in the analysis area is slower than the growth rate of the same sector in the reference region.

b. A positive PS value (Mij) or> 0 indicates that the growth rate of sector $\mathrm{i}$ in the analysis area is faster than the growth rate of the same sector in the reference region.

The meaning of DS (Cij) value

a. A positive DS value $(\mathrm{Cij})$ or $>0$ indicates that the idi sector in the analysis area has higher competitiveness compared to the competitiveness of the same sector in the reference region.

b. A positive DS value $(\mathrm{Cij})$ or $>0$ indicates that sector $\mathrm{i}$ in the analysis area has higher competitiveness compared to the competitiveness of the same sector in the reference region.

To find out the amount of sectoral added value and components of regional growth with the following formulation:

$$
\mathrm{Dij}=\mathrm{Nij}+\mathrm{Mij}+\mathrm{Cij}
$$

To calculate the components of Nij, Mij, Cij can be calculated:

$$
\begin{aligned}
& \text { Nij = Eij.rn } \\
& \text { Mij = Eij (rin-rn) } \\
& \text { Cij = Eij (rij-rn) }
\end{aligned}
$$

Source: (Muta'ali, 2015)

Note :

Di, $j=$ Changes in sector / subsector $i$ GDP in Palopo City

$N i, j=$ Changes in sector / subsector $i$ GDP in Palopo City caused by the influence of regional growth in South Sulawesi Province

Mi, $j=$ Changes in sector / subsector $i$ GDP in Palopo City caused by the influence of sector $i$

economic

South Sulawesi Province

$C i, j=$ Changes in sector / subsector $i$ GDP in Palopo City caused by sector i competitive in Palopo City

The growth rate values are formulated as follows:

$$
\begin{aligned}
& \text { rij }=(E * i j-E i j) / E i j \\
& r i n=(E * i n-E i n) / E i n \\
& r n=(E * n-E n) / E n
\end{aligned}
$$

Source: (Ma'mun dan Irwansyah, 2013)

Note : 


$$
\begin{array}{ll}
\text { rin } & =\text { Growth rate of sector } i \text { South Sulawesi Province } \\
\text { rij } & =\text { Growth rate of sector } i \text { in the City of Palopo } \\
\text { Eij } & =\text { GDP sector / subsector } i \text { in Palopo City in the beginning of the analysis } \\
E * i j & =\text { sector / subsector } i \text { GDP in Palopo City at the end of the analysis } \\
\text { Ein } & =\text { GDP sector / subsector } i \text { in South Sulawesi Province in the initial year of } \\
E n & =\text { total GDP in South Sulawesi Province in the initial year of analysis } \\
E i * n & =\text { sector / subsector } i \text { GDP in South Sulawesi Province the final year of } \\
E * n & =\text { total GDP in South Sulawesi Province at the end of the analysis }
\end{array}
$$

analysis

analysis

Based on these formulations, the Shift Share equation for sector i can be summarized as follows:

$$
\begin{aligned}
& \text { Dij = Eij.rn + Eij (rin-rn) + Eij (rij-rin) } \\
& \text { SNij = Mij + Cij }
\end{aligned}
$$

Source: (Muta'ali, 2015)

Note :

SNij $\quad=\quad$ Net Shift (Net Shift) sector $i$ in Palopo City

The Meaning of Net Shift :

a. SNij > O indicates that sector $i$ growth in the analysis area is progressive, and

b. SNij < O shows that the growth of sector $i$ in the analysis area is not progressive.

Shift Share Analysis Marguillas are used to break down the differential shift component (DS) into a component of specialization and competitive advantage or better known as the effect of allocation effects (Aij). These components can identify the existence of the leading sector in the Palopo City area based on the criteria of specialization and competitive advantage. To determine the effect of an economic allocation effect on a region with the following formulation:

$$
\begin{array}{ll}
\mathrm{E} * \mathrm{ij} & =\mathrm{Ej}(\mathrm{Ein} / \mathrm{En}) \\
\mathrm{Ci} * \mathrm{ij} & =\mathrm{E} * \mathrm{ij}(\mathrm{rij}-\mathrm{rn}) \\
\mathrm{Aij} & =(\mathrm{Eij}-\mathrm{E} * \mathrm{ij})(\text { rij }- \text { rin }) \\
\mathrm{Dij} & =\mathrm{Eij}(\mathrm{rn})+\mathrm{Eij}(\text { rin-rn })+\mathrm{E} * \mathrm{ij}(\mathrm{rij}-\mathrm{rin})+(\mathrm{Eij}-\mathrm{E} * \mathrm{ij})(\mathrm{rij}-\mathrm{rin})
\end{array}
$$

Source: (Ma'mun dan Irwansyah, 2013)

Note :

Aij $\quad=$ Effect of sector $i$ allocation in Palopo City

$($ Eij-E $* i j) \quad=$ Level of specialization of sector $i$ in the City of Palopo

(rij-rin) = Level of competitive advantage sector $i$ in the City of Palopo

Table 1 The possibilities that occur from the allocation effect

\begin{tabular}{ccccc}
\hline No & Rij-rin & Eij-E*ij & Competitive Advantage & Specialization \\
\hline 1 & $>0$ & $>0$ & Yes & Yes \\
2 & $>0$ & $<0$ & Yes & No \\
3 & $<0$ & $>0$ & No & Yes \\
4 & $<0$ & $<0$ & No & No \\
\hline
\end{tabular}

Source: (Muta'ali, 2015) 


\section{RESULTS AND DISCUSSION}

\section{Classic Shift Share Analysis Results}

Classical Shift Share Analysis is one of the analyzes used in determining the leading sector of an area based on the criteria of growth rate and sectoral added value to the regional economic development of Palopo City. The basic theory of Shift Share analysis assumes that regional economic growth or sectoral added value is basically influenced by three main components including Regional Share (RS), Proportional Shift (PS) and Differential Shift (DS). Shift Share Analysis describes the growth and shifts in the regional economic sector that occurred in Palopo City in the period 2013-2018. The results of the Shift Share analysis calculation are as follows:

Table 2. Shift Share Analysis of Regional Economic Sectors in Palopo City in 2013-2018 (Million Rupiah)

\begin{tabular}{|c|c|c|c|c|c|}
\hline No & Sector & Nij (RS) & $\mathrm{Mij}$ (PS) & Cij (DS) & Dij \\
\hline 1 & $\begin{array}{l}\text { Agriculture, Forestry, and } \\
\text { Fisheries }\end{array}$ & $294.660,23$ & $-18.666,86$ & $-141.021,44$ & $134.971,93$ \\
\hline 2 & Mining and Excavation & $2.432,28$ & $-898,41$ & $-571,00$ & 962,87 \\
\hline 3 & Processing Industry & $43.889,66$ & $-9.144,30$ & $-9,182.62$ & $25.562,74$ \\
\hline 4 & Electricity and Gas Supply & $1.621,86$ & 154,59 & 64,29 & $1.840,74$ \\
\hline 5 & $\begin{array}{l}\text { Water Supply, Waste } \\
\text { Management, Waste and } \\
\text { Recycling }\end{array}$ & $4.984,50$ & $-2.140,87$ & 141,09 & $2.984,71$ \\
\hline 6 & Construction & $236.086,95$ & $17.494,08$ & $-76.612,69$ & $176.968,33$ \\
\hline 7 & $\begin{array}{l}\text { Wholesale and Retail Trade, Car } \\
\text { and Motorcycle Repair }\end{array}$ & $322.915,75$ & $104.903,65$ & $101.563,83$ & $529.383,23$ \\
\hline 8 & Transportation and Warehousing & $81.569,12$ & $-5.853,97$ & $17.864,48$ & $93.579,64$ \\
\hline 9 & $\begin{array}{l}\text { Provision of Accommodation and } \\
\text { Food Beverages }\end{array}$ & $18.041,63$ & $15.094,72$ & $-15.926,84$ & $17.209,51$ \\
\hline 10 & Information and Communication & $83.101,90$ & $20.351,16$ & $3.374,37$ & $106.827,43$ \\
\hline 11 & Financial and Insurance Services & $123.460,60$ & $-3.880,14$ & $-27.840,52$ & $91.739,95$ \\
\hline 12 & Real Estate & $72.894,69$ & $-12.947,89$ & 981,82 & $60.928,62$ \\
\hline 13 & Company Services & $1.438,62$ & 105,70 & $-322,98$ & $1.211,35$ \\
\hline 14 & $\begin{array}{l}\text { Government Administration, } \\
\text { Mandatory Defense, and Social } \\
\text { Security }\end{array}$ & $116.805,64$ & $-41.214,91$ & $16.738,33$ & $92.329,06$ \\
\hline 15 & Educational Services & $77.310,56$ & $3.823,64$ & $-16.185,93$ & $64.948,26$ \\
\hline 16 & $\begin{array}{l}\text { Health Services and Social } \\
\text { Activities }\end{array}$ & $36.915,96$ & $10.482,92$ & $2.511,59$ & $49.910,48$ \\
\hline 17 & Other Services & $20.747,99$ & $8.446,48$ & $-10.570,33$ & $18.623,15$ \\
\hline
\end{tabular}

Source: Processed data

Table 2. shows the results of the calculation of the Shift Share analysis of the Regional Share (RS) component of the Palopo City economic sector showing that the RS value is positive at 1.538 trillion, meaning that the growth of GDP in South Sulawesi Province has a positive influence on the growth of Palopo City's GDP. The second component of the Shift Share analysis, Proportional Shift (PS) is positive at 86 billion, indicating that the economic growth of the Palopo City area is faster than the economic growth of South Sulawesi Province. Palopo City's economic growth is concentrated in sectors that have a faster growth rate than the growth rate of the same sector in South Sulawesi Province. Some sectors that have a fast growth rate are the electricity and gas procurement sector; water supply, waste management, waste and recycling sectors; wholesale and retail trade, car and motorcycle repair; the sector of providing accommodation and food and drink; information and communication sector; corporate service sector; education service sector; health service sector and social activities; and other service sectors. 
Shift Share analysis of the Differential Shift (DS) component is negative, indicating that the component of competitiveness or competitive advantage has a negative impact on the economic growth of Palopo City. In general, changes in Palopo City's GDP are due to the competitiveness or competitive advantage of the regional economic sector which is lower than the provincial sector's competitiveness at the same level. ) in the 2013-2018 period, there was a positive 1.4 trillion indicating that there was a positive growth of sectoral value added (Dij) in Palopo City where the large and retail trade sectors; car and motorcycle repairs have the largest contribution to the shift in the growth of the total value added (GDP) of Palopo City (36\%). Then followed by the construction sector (12.03\%), agriculture, forestry \& fisheries (9.18\%), the information and communication sector $(7.26 \%)$, the transportation and warehousing sector $(6.36 \%)$ and the government administration sector, compulsory defense and social security (6.28\%). The sector that has high added value is considered as the leading sector because it has a large contribution as an economic driver and ultimately becomes a new source of income for the Palopo City area.

\section{Estaban Marguillas Shift Share Analysis Results}

Estaban Marguillas Shift Share Analysis is used to overcome the weaknesses of the Classical Shift Share analysis, namely the weighting problem caused as a result of competition from the three components of regional economic growth. Estaban Marguillas Shift Share analysis is used to determine the leading sector of a region based on the criteria of competitive advantage and sector specialization. The calculation result of Estaban Marguillas Shift Share analysis on the performance of the economic sector in Palopo City in 2013-2018 is as follows.

Table 3. Results of Esteban Marquillas Modified Shift Share Analysis on Regional Economic Sector Performance in Palopo City 2013-2018.

\begin{tabular}{|c|c|c|c|c|c|c|}
\hline No & Sector & $\begin{array}{l}\mathbf{R i j}- \\
\text { rin }\end{array}$ & $E_{\mathbf{i j}}-\mathbf{E}^{*} \mathbf{i j}$ & $\mathbf{A} \mathbf{i j}$ & $\begin{array}{l}\text { Competitive } \\
\text { Advantage }\end{array}$ & Specializ ation \\
\hline 1 & $\begin{array}{l}\text { A griculture,F orestry, } \\
\text { and Fisheries }\end{array}$ & -0.20 & $-81.150,95$ & $16.451,12$ & No & No \\
\hline 2 & $\begin{array}{l}\text { Mining and } \\
\text { Excavation }\end{array}$ & -0.10 & $-215.705,64$ & $21.449,70$ & No & No \\
\hline 3 & Processing Industry & -0.09 & $-407.232,77$ & $36.089,85$ & No & No \\
\hline 4 & $\begin{array}{l}\text { Electricity and Gas } \\
\text { Supply }\end{array}$ & 0.02 & 488,06 & 8,20 & Yes & Y es \\
\hline 5 & $\begin{array}{l}\text { Water Supply, Waste } \\
\text { Management, Waste } \\
\text { and Recycling }\end{array}$ & 0.01 & $-2.914 .179,29$ & $-34.939,84$ & Yes & No \\
\hline 6 & Construction & -0.14 & $122.031,79$ & $-16.774,13$ & No & Yes \\
\hline 7 & $\begin{array}{l}\text { Wholesale and Retail } \\
\text { Trade, Car and } \\
\text { Motorcycle Repair }\end{array}$ & 0.13 & $257.439,19$ & $34.297,51$ & Yes & Yes \\
\hline 8 & $\begin{array}{l}\text { Transportation and } \\
\text { Warehousing }\end{array}$ & 0.09 & $51.185,84$ & $4.748,46$ & Yes & Yes \\
\hline 9 & $\begin{array}{l}\text { Provision of } \\
\text { Accommodation and } \\
\text { Food Beverages }\end{array}$ & $-0,37$ & $-2.000 .743,04$ & $748.140,67$ & No & No \\
\hline 10 & $\begin{array}{l}\text { In formation and } \\
\text { Communication }\end{array}$ & 0.02 & $-34.078,35$ & $-586,14$ & Yes & No \\
\hline 11 & $\begin{array}{l}\text { Financial and } \\
\text { Insurance Services }\end{array}$ & -0.10 & $163.926,05$ & $-15.657,95$ & No & Yes \\
\hline 12 & Real Estate & 0.01 & $39.423,31$ & 224,92 & Yes & Yes \\
\hline 13 & Company Services & -0.10 & $-12.281,37$ & $1.204,07$ & No & No \\
\hline 14 & $\begin{array}{l}\text { Government } \\
\text { Administration, } \\
\text { Mandatory Defense, } \\
\text { and Social Security }\end{array}$ & 0.06 & $-3.357 .248,75$ & $-203.783,96$ & Yes & No \\
\hline 15 & Educationa1 Services & -0.09 & $-16.818,05$ & $1.491,46$ & No & No \\
\hline 16 & $\begin{array}{l}\text { Health Services and } \\
\text { Socia1 Activities }\end{array}$ & 0.03 & $19.897,98$ & 573,43 & Yes & Y es \\
\hline 17 & Other Services & -0.22 & $3.223,97$ & $-695,73$ & No & Yes \\
\hline
\end{tabular}

Source: Processed data

Based on the calculation results of Estaban Marguillas Shift Share analysis, there are several sectors that specialize as well as having a competitive advantage in the City of Palopo, namely the electricity and gas procurement sector, the wholesale 
and retail trade sectors; car and motorcycle repair, transportation and warehousing, real estate, and health services and social activities. Sectors that are specialized and have competitive advantages in the City of Palopo are expected to be able to dominate the market not only in the area of South Sulawesi Province but also nationally. The existence of appropriate policies and development programs towards sectors that specialize and have competitive advantages are expected to encourage economic growth region in order to improve the welfare and prosperity of the people in Palopo City.

\section{CONCLUSION}

1. The calculation results of the Shift Economic analysis of the Palopo City regional economy sector show the electricity and gas procurement sector; wholesale and retail trade, car and motorcycle repair; information and communication sector; and the health service sector and social activities have positive Regional Share (RS), Proportional Shift (PS) and Differential Shift (DS) values together. The positive value of the sector illustrates the positive growth of the regional sector in the City of Palopo due to the influence of growth from the same sector in the province of South Sulawesi, which has a faster growth rate and is highly competitive. The net shift (Netto Shift) of the sector is positive indicating the growth of the sector is progressive.

2. Based on the calculation results of the classic Shift Share analysis of the three main components of the growth of the Palopo City Region namely Regional Share (RS), Proportional Shift (PS) and Differential Shift (DS) show that the shift and growth of the total value added (Dij) GDP within a period of time 2013-2018 is positive. These conditions indicate that there has been positive growth in the economy of the City of Palopo. Wholesale and retail trade sector; car and motorcycle repair has the most contribution to the growth of the Palopo City GDP value followed by the construction sector, agriculture, forestry $\&$ fisheries sector, information and communication sector, transportation and warehousing sector and government administration, defence and mandatory social security sectors.

3. Estan Marguillas Shift Share Analysis shows the electricity and gas procurement sector, wholesale and retail trade sectors; car and motorcycle repair, the transportation and warehousing sector, the real estate sector, and the health service sector and social activities are specialized sectors as well as having a competitive advantage in the City of Palopo.

4. Sectoral shifts and economic growth in the Palopo City area based on the analysis of the Classic Shift Share and Shift Share modifications Estaban Marguillas shows that 1) the electricity and gas procurement sector, 2) the wholesale and retail trade sector; car and motorcycle repairs, and 3) the health service sector and social activities are the leading sectors and are expected to be the main drivers of the regional economy of Palopo City because they have fast growth rates, progressive sectoral growth, positive value-added sectors and are sectors that become specialization and has a competitive advantage in the City of Palopo.

\section{Recommendations}

1. Palopo City Government needs to prioritize regional development by prioritizing the development of regional leading sectors not only in the wholesale and retail trade sector, car and motorcycle repair but also in the electricity and gas procurement sector, as well as the health service sector and social activities. The steps that can be taken by the government include simplification of policies or regional regulations, bureaucratic reform, ease of taking care of licensing and integrated services to attract investors to invest and invest in promising sectors.

2. Required planning, budgeting, implementation and controlling and effective controlling policies to sustain competitive advantage and specialization in a sustainable manner.

3. The results of the research carried out are expected to be input for the government, especially Bappeda and the relevant DPOs in preparing program plans and development activities for the leading regions and as a material for revision of regional planning documents in the future.

\section{REFERENCE}

[1] Amalia, F. (2012) 'Penentuan Sektor Unggulan Perekonomian Wilayah Kabupaten Bone Bolango Dengan Pendekatan Sektor Pembentuk PDRB', 11(2), pp. 196-207. doi: https://doi.org/10.15408/etk.v11i2.1893.

[2] Badri, J. (2009) 'Analisis Potensi dan Pertumbuhan Ekonomi Daerah Kabupaten Solok'.

[3] Brown, D. L., Greskovits, B. and Kulcsár, L. J. (2007) 'Leading Sectors and Leading Regions : Economic Restructuring and Regional Inequality in Hungary since 1990', 31(September), pp. 522-543. doi: 10.1111/j.1468-2427.2007.00738.x.

[4] Chandra, R. (2006) 'Currie' s “ Leading Sector " Strategy of Growth: an Appraisal', 42(3), pp. 490-508. doi: $10.1080 / 00220380600576391$.

[5] Gunawan, I. (2015) 'Analisis Strategi Pengembangan Usaha Komoditas Unggulan Pertanian di Kabupaten Rokan Hulu', 3(2), pp. 1-17. doi: http://dx.doi.org/10.30606/js.v3i2.470. 
[6] Ma'mun, D. and Irwansyah, S. (2013) 'Analisis Pergeseran Struktur Ekonomi dan Identifikasi Sektor Potesial Wilayah Pengembangan (Studi Kasus di Kabupaten Bekasi, Provinsi Jawa Barat)', 2(April), pp. 7-28.

[7] Muta'ali, L. (2015) Teknik Analisis Regional. Yogyakarta: Badan Penerbit Fakultas Geografi (BPFG) Universitas Gajah Mada.

[8] Sun’an, M. and Senuk, A. (2015) Ekonomi Pembangunan Daerah. Jakarta: Mitra Wacana Media.

[9] Syahputra, H., Hamzah, A. and Syahnur, S. (2015) 'Analisis Sektor Unggulan Dan Perubahan Struktur Perekonomian Kabupaten Aceh Barat', 3(3), pp. 56-68. 